Article

\title{
Modeling for Determinants of Human Trafficking: An Empirical Analysis
}

\author{
Seo-Young Cho \\ Faculty of Business and Economics, Philipps-University of Marburg, Barfüßertor 2, 35037 Marburg, Germany; \\ E-Mail: seo.cho@wiwi.uni-marburg.de; Tel.: +49-6421-28-23996; Fax: +49-6421-28-21740
}

Submitted: 23 June 2014 | Accepted: 6 August 2014 | Published: 23 February 2015

\begin{abstract}
This study aims to identify robust push and pull factors of human trafficking. I test for the robustness of 70 push and 63 pull factors suggested in the literature. In doing so, I employ an extreme bound analysis, running more than two million regressions with all possible combinations of variables for up to 153 countries during the period of 1995-2010. My results show that crime prevalence robustly explains human trafficking both in destination and origin countries. Income level also has a robust impact, suggesting that the cause of human trafficking shares that of economic migration. Law enforcement matters more in origin countries than destination countries. Interestingly, a very low level of gender equality may have constraining effects on human trafficking outflow, possibly because gender discrimination limits female mobility that is necessary for the occurrence of human trafficking.
\end{abstract}

\section{Keywords}

extreme bound analysis; human trafficking; push and pull factors; robustness

Issue

This article is part of the special issue "Perspectives on Human Trafficking and Modern Forms of Slavery", edited by Siddharth Kara (Harvard Kennedy School of Government, USA).

(C) 2015 by the author; licensee Cogitatio (Lisbon, Portugal). This article is licensed under a Creative Commons Attribution 4.0 International License (CC BY).

\section{Introduction}

Human trafficking is an emerging problem that is rapidly growing today (Interpol, 2009). Income disparity between the affluent North and (relatively) impoverished South is still considerable, if not increasing, and people's aspirations to seek better opportunities have become greater, as information on life in other parts of the world is now more readily available than ever before due to the development of mass media news outlets and the internet. Economic motivation explains the phenomenon of human trafficking to a great extent, given that most victims of human trafficking are initially migrants with economic reasons (International Organization for Migration [IOM], 2012).

However, as far as the causes of human trafficking are concerned, an important question is still to be answered. Why do some people attempting to migrate elsewhere fall victim to human trafficking, while others do not? Furthermore, why is this phenomenon increas- ing? To the present, the outcome of investigations on these questions is inconclusive and there is little consensus on the prime factors determining human trafficking in the literature. Among many factors suggested in the literature, some factors are important determinants of human trafficking in some studies, while in others they do not have a significant impact and other factors are suggested as crucial causes, instead. Such discrepancy is mainly caused by several critical challenges that human trafficking researchers are currently facing.

First, as research on human trafficking is still in its infancy, there is no exemplary model identifying the determinants of human trafficking. Thus, the choice of variables for estimation tends to depend on heuristic approaches rather than systematic ones. Given this background, the results of empirical investigations on human trafficking are more likely to be susceptible to the choice of variables. Moreover, difficulties in identifying robust factors are exacerbated due to the poor quality of human trafficking data because human traf- 
ficking is a clandestine, criminal activity of a complex nature, and therefore current discussions heavily depend on fragmented information that is available.

In this paper, I try to overcome the incompleteness of research on human trafficking and propose a baseline model by reviewing a comprehensive list of the literature and empirically assessing the robustness of all human trafficking factors suggested in the literature. My investigation aims to identify robust factors, while controlling for many other overlapping factors. To do so, I employ an extreme bound analysis (EBA) that identifies factors robust to the choice of other control variables. By using this method, we can single out variables which survive in some million regressions, with all possible combinations of other control variables (Leamer, 1983; Levine \& Renelt, 1992; Sala-i-Martin, 1997). This method is particularly sensible if there is no consensus on the choice of explanatory variables in the literature, which is the case of human trafficking research (another exemplary study using the EBA in this respect is Hegre and Sambanis' (2006) sensitivity analysis on the determinants of civil wars). Moreover, in order to reduce potential estimation biases caused by measurement errors and selection biases in human trafficking data, I make a use of the three different global measurements on human trafficking in-/outflows-United Nations Office on Drugs and Crime (UNODC) (2006), United States Department of State (2011-2014), and International Labor Organization (ILO) (2005)-, and compare the results of the these measurements.

From the literature consisting of 19 major empirical studies systematically analyzing the causes of human trafficking, I gather 70 factors pushing victims to be trafficked from origin countries, and 63 factors pulling victims trafficked into destination countries. The factors reflect diverse aspects of human trafficking, but can be categorized into four pillars - migration, crime, vulnerability, and policy and institutional efforts. The four prime pillars explain: (1) which groups of people take risky migration options and therefore likely fall victim to human trafficking (migration and vulnerability pillars); (2) and how/under which environments those vulnerable migrants are more easily trafficked (crime and policy/institutional efforts pillars).

My empirical analysis revisits and assesses the relevance of the four pillars on human trafficking. First, my findings suggest that the crime pillar of human trafficking is a robust factor pushing and pulling victims in origin and destination countries, respectively. Second, several factors facilitating migration closely explain human trafficking: income and globalization-in particular, exposure to information. Third, the institutional quality pillar matters in origin countries, while the factors of this pillar do not turn out to have a significant impact in destination countries. Last, empirical assessments on the vulnerability pillar indicate controversial findings. Interestingly, gender discrimination and low development-indicators of the vulnerability of people to human trafficking-do not demonstrate robust effects, and some gender-related indicators such as high fertility rates have constraining effects that are contrary to expectations. It seems that gender discrimination does not have a straightforward relation with human trafficking. In other words, a very low level of gender equality also constrains human trafficking, possibly by discouraging female mobility.

My findings provide a baseline set of robust push and pull factors based on empirical investigation on the four pillars of human trafficking. By doing so, this paper suggests a reference for further studies closely looking into the specific circumstances of human trafficking, and offers policy relevance in terms of suggesting in which areas we should focus on in order to combat the problem.

\section{Four Pillars of Human Trafficking}

The literature puts forward a large set of push and pull factors of human trafficking, the first determining the supply of victims from countries of origin, and the latter determining demand for labor provided by victims in destination countries. The following four pillars provide a basic framework to explain the different factors of human trafficking in origin and destination countries. Each pillar is, of course, not exclusive and many push and pull factors can be included in more than one pillar.

\subsection{Migration}

IOM Counter Trafficking Module (CTM), a survey of about 25,000 victims, shows that most trafficking victims were initially recruited for migration through personal connections or professional agencies, while less than $5 \%$ in the sample of the survey were kidnapped. This observation indicates that, from the outset, the majority of trafficking victims voluntarily decide to migrate elsewhere. The literature also supports a linkage between migration and human trafficking. Mahmoud and Trebesch (2010) suggest that having a migrant in a family tends to motivate other family members to migrate and also increases the probability of being trafficked. Akee, Basu, Chau and Khamis (2010) and Akee, Bedi, Basu and Chau (2014) also show that migration between two countries induces human trafficking flows between them.

With this in mind, various factors promoting migration can likely explain human trafficking. Among them, income is a crucial factor suggested in the literature, given that migrants commonly come from lower-income countries to wealthier countries. The economic motivation of migrants is shared by victims of human trafficking who initially wanted to migrate for economic betterment (IOM, 2012). In relation to that, employment opportunities for the low-skilled in origin countries and 
demand for cheap labor in destinations-particularly in prostitution, agricultural and informal industries where (potential) victims of human trafficking are typically employed-can shape certain migration patterns more prone to human trafficking. Additionally, factors facilitating migration and human mobility across borders-such as globalization and migration policy-can also provide a linkage to human trafficking flows.

\subsection{Vulnerability}

Above, I addressed the linkage between migration and human trafficking because most trafficking victims are initially migration seekers. Thus, it is reasonable to expect that migration factors can provide at least rudimentary indicators of human trafficking; therefore, determinants of migration are overlapped with push and pull factors of human trafficking to some extent. However, the pool of migrants is not identical to that of trafficking victims, and thus one needs to raise a further question in explaining human trafficking: why do some migrants fall victim to human trafficking, while others do not? In other words, what makes some migrants more vulnerable to human trafficking? In tackling this question, a vulnerability assessment is noteworthy (Akee, Basu, Chau, \& Khamis, 2012).

The literature widely points out that the vulnerable position of women in society is a powerful push factor of human trafficking outflows (Bettio \& Nandi, 2010; Clawson \& Layne, 2007; Danailova-Trainor \& Belser, 2006; Di Tommaso, Shima, Strøm, \& Bettio, 2009). Human trafficking is apparently gender-based violence, the majority of victims being females exploited in the sex industry (UNODC, 2006; IOM, 2012). Among many types of gender discrimination, women's vulnerable position in employment likely pushes them to take risky migration options which may turn into human trafficking.

There are also other factors making people more vulnerable to human trafficking. As discussed above, income is both a push and pull factor of human trafficking. However, it might be perceived that income differences actually motivate people to undertake risky migration because such a difference can make people resentful towards their current situation, and raise expectations for a better life. In this regard, income inequality can be a strong factor pushing underprivileged people to be trafficked (Jac-Kucharski, 2012; Mo, 2011). Also, conflicts, human rights violations, and socioeconomic/political unrest lead people into desperately wanting to escape from their current living situation, therefore making people under such circumstances more vulnerable to human trafficking (Akee et al., 2010; Frank, 2011).

\subsection{Crime}

While human trafficking is associated with certain pat- terns of migration, it is, at the same time, a crime involving the illegal transportation of people and exploitation of them (UN, 2000). In fact, human trafficking occurs only if there are perpetrators exploiting vulnerable migrants. According to Interpol (2009), human trafficking is the third largest transnational crime, bringing large profits for organized criminal groups. Much of the criminology literature documents the connection between human smuggling, human trafficking, and organized crime activities (Aronowitz, 2001). The studies show that organized criminal organizations-which are already involved in human smuggling and drug/arms trafficking-are now expanding their business into trading victims of human trafficking for exploitative labor. These studies point out that such involvement of criminal organizations enlarges the scope of human trafficking operation, with profits made through such business amounting to billions of dollars every year (Belser, 2005). In quantitative empirical studies, Akee et al. (2014) pioneered a study on traffickers' incentives to operate human trafficking business in different countries. Their study suggests that the level of law enforcement and corruption, as well as prostitution policy, can affect traffickers' incentives in selecting countries for their criminal operations.

Based on the discussions in the literature, the prevalence of human trafficking can be determined by profitability, which is related to market sizes and conditions in which trafficking victims are typically employed (e.g., prostitution, domestic servitude, agriculture and other informal sectors), the risk of being caught (law enforcement level), and the presence of already established criminal organizations with respect to operating costs and experience in trafficking businesses. Indeed, the crime aspect of human trafficking is something that has widely been neglected in the empirical literature, and thus linkages between human trafficking and the prevalence of crime are still empirically inconclusive.

\subsection{Policy and Institutional Efforts}

As human trafficking is a crime, institutional efforts in combating the crime play an important role. Human trafficking researchers discuss law enforcement and the level of corruption as important factors, both in origin and destination countries (Akee et al. 2010, 2014; Cho, Dreher, \& Neumayer, 2013; 2014; Jakobsson \& Kotsadam, 2013). Besides the general rule of law, specific antitrafficking measures are also crucial to addressing the problem (Cho et al. 2014; Cho \& Vadlamannati, 2012; Potrafke, 2013). The anti-trafficking measures include prosecution policy against traffickers, protection policy for victims, and prevention policy (UN, 2000). These measures are essential as human trafficking is a specific form of crime which cannot be fully addressed by other existing laws.

Furthermore, general developmental policies are 
also important because the root causes of human trafficking are closely related to developmental problems such as poverty, inequality and gender discrimination bringing about risks for human security.

\section{Data: Measuring Human Trafficking}

One of the challenges of investigating human trafficking is the lack of reliable data (Kangaspunta, 2003). As human trafficking is a clandestine, illicit criminal activity, the true magnitude of the problem is still unknown. Furthermore, despite the international definition of human trafficking adopted by the United Nations (UN)' Anti-trafficking Protocol (2000), it is hard to clearly distinguish this phenomenon from illegal migration and forced labor in practice, with many countries using different variations of the definition (for instance, including sex trafficking only, or applying the 'forced labor' concept). In fact, at present, there is no internationally comparable official statistics capturing the magnitude of human trafficking (van Dijk, 2008). The United Nations Surveys on Crime Trends and the Operations of Criminal Justice Systems (UNCTS) provide police statistics on the reported number of human trafficking cases for the period of 2005-2008, covering a maximum of 80 countries. ${ }^{1}$ However, these statistics hardly reflect the true extent of the problem, with variations in statistics across countries and time instead capturing the level of law enforcement and differences in the definition of human trafficking between countries (Harrendorf, Heiskanen, \& Malby, 2010).

Despite the problems of human trafficking data collection mentioned above, there are several international attempts to quantify the level of human trafficking by utilizing various sources, including media reports, expert judgments, and qualitative information from fieldwork. Among them, three datasets provide quantitative information on the magnitude of human trafficking which is comparable across countries. First, the United Nations Office on Drug and Crime (UNODC, 2006) proposes an incidence reporting index, grading the level of human trafficking in/outflows on a scale of 0 to 5 based on incidences coded in international reports and media. This index covers up to 161 countries and aggregates numbers over the period of 19962003. Second, the United States Department of State (2001-2014) categorizes countries into major destinations/origins based on the classification of whether a country experiences more than 100 reported cases of in/outflows in a given year. The US annual data is a dummy variable covering up to 190 countries from 2001 to 2013. Third, the International Labor Organization collected information on incidences through its

\footnotetext{
${ }^{1}$ Additionally, there are EU-wide statistics on human trafficking collected and published by the European Commission (2013), covering 34 member states from 2008 to 2010.
}

global reporting system and provides the aggregate number of cases during the period of 1995-2000, covering a maximum of 74 countries. $^{2}$

These selected datasets have several advantages. First, they are gathered by a single collection body under a unified definition of human trafficking, minimizing noises caused by disparities in collection methods and definitions. Second, as they are not police statistics, these datasets are comparatively less susceptible to biases caused by law enforcement efforts. However, these data have some shortcomings as well. First, they are still subject to biases in data collection because they depend on reported incidences. Second, the UNODC and ILO data provide aggregate quantities without variations over time, while the panel data provided by the US Department of State is a dummy variable with few variations. With the constraints of the available data in mind, I employ each of the three datasets in my analysis and compare the results in order to reduce any biases and fragmentation each dataset has. Furthermore, I include control variables capturing as many reporting biases as possible in my estimation model. In doing so, the UNODC dataset serves as the main measurement and the other two as check for the robustness because the UNODC data follows the definition of human trafficking suggested by the UN Antitrafficking Protocol (2000), and thus, the collected information reflects the internationally accepted scopes of human trafficking most precisely. The definitions of human trafficking adopted by the ILO and the United States are widely similar to that of the UNODC with minor variations-ILO not specifying forms of human trafficking and the US specifically mentioning commercial sex as a cause of human trafficking. The detailed definitions of human trafficking and information on the three datasets are provided in Appendix A.

\section{Research Design}

The aim of my study is to select robust push and pull factors of human trafficking. In order to pursue this goal, I follow two procedures. First, I review all major existing literature in the field of human trafficking, in particular empirical studies, and collect all factors suggested by these studies. Indeed, empirical studies are rare in this field mainly because of the lack of data. With the best of my knowledge, I identified and selected 19 studies $^{3}$-to date-empirically investigating the

\footnotetext{
2 The IOM CTM provides enriched information on the characteristics of victims; however, this dataset is not suitable for a macro-analysis given that it is micro-survey data without a reference to the magnitude of the problem at the country level.

${ }^{3}$ Akee et al. (2010, 2012, 2014), Bales (2007), Belser (2005), Bettio and Nandi (2010), Cho (2013), Cho et al. (2013), Clawson and Layne (2007), Danailova-Trainor and Belser (2006), Di Tommaso et al. (2009), Frank (2011), Jac-Kucharski (2012), Jakobsson and Kotsadam (2013), Mahmoud and Trebesch (2010),
} 
determinants of human trafficking by using systematic analyses. Through reviewing the currently available studies, I identify 70 (potential) push factors in countries of origin, and 63 (potential) pull factors in countries of destination. The full list of the push and pull factors suggested in these studies, can be found in Appendices $B$ and $C$.

As mentioned earlier, it is a challenging task to distinguish between robust factors while controlling for many other factors with overlapping effects, in particular because there are no established findings in the human trafficking literature. With these challenges in mind, I try to identify robust factors of human trafficking by employing an extreme bound analysis. The extreme bounds analysis (EBA), proposed by Leamer (1983), Levine and Renelt (1992) and Sala-i-Martin (1997), is a method to check the statistical significance of the effect of a factor in all possible specifications, with different combinations of other factors.

The main advantage of this method is that it distinguishes factors robust to the choice of other control variables, and therefore enables to identify 'true' variables (Sala-i-Martin, 1997), which explain human trafficking. However, the EBA approach may still be unable to identify a full set of robust explanatory variables if most factors suggested in the literature are not correlated systematically with human trafficking at all. Such a potential problem may not be trivial in the literature of human trafficking because this is a new field with a thin volume of literature and furthermore the poor quality of data on human trafficking makes empirical research difficult. Acknowledging the limitation, I further check the credibility of the suggested factors with qualitative studies on human trafficking. Among them, Cameron and Newman (2008) list 32 structural and proximate factors of human trafficking based on numerous field reports of international organizations and expert opinions. The majority of the factors suggested in their study overlaps with the push and pull factors documented from the empirical studies I gathered. Moreover, the UNODC (2008) also addresses nine socioeconomic, political conditions making people vulnerable to human trafficking, supporting the selection of the push and pull factors in the empirical literature. Due to this fact, the 70 push and 63 pull factors gathered in this paper likely represent determinants of human trafficking to at least a considerable degree.

In performing the EBA analysis I use the three different human trafficking datasets described in Section 3. In doing so, the UNODC data is used as the main measurement and the other two as for a robustness check. In the end, the results of the three measurements are compared in order to minimize any bias each dataset has - this procedure is described in more

Mo (2011), Rao and Presenti (2012), Smith and Smith (2010), and Zhang, Finch and Qin (2011). detail in Section 5 .

The following equation is estimated for the EBA analysis.

$$
y_{i}=\delta_{C} C+\delta_{E} E+\delta_{Z} Z+\omega
$$

In this equation $y$ indicates the level of human trafficking in-/outflows, respectively, and vector $C$ includes a "commonly accepted" explanatory variable that is widely suggested in the literature and therefore always included in every regression. In this study, income (logged GDP pc) is selected, because most studies examined here unanimously suggest "income" as both a pull and push factor of human trafficking (see Appendices $B$ and $C$ ), given that most human trafficking victims are initially migrants seeking better economic opportunities in a more affluent world (see discussions in Section 2.1).

All other variables under investigation, except for "income", enter the vector E one by one, with each variable being tested, while controlling for income and three other control variables in the vector $Z$ (Levine and Renelt, 1992). ${ }^{4}$ The vector $Z$ contains three control variables in each regression and all variables, except for 'income' and the variable currently being examined in $E$, enter into $Z$. The composition of explanatory variables in $Z$ changes for each regression, as all possible combinations of control variables are being tested. $\delta$ denotes the coefficient of the respective variables and $\omega$ is the idiosyncratic error term.

As the UNODC and ILO data do not have time variations, I conduct a cross-sectional analysis by employing an ordered probit estimation method with the UNODC data, capturing the ordered structure of the dependent variable (score $0-5$ ), and a negative binomial regression method with the ILO data, addressing the nature of the count variable. On the other hand, the US data contains annual variations (2000-2010), therefore I perform a panel analysis with a probit estimation method as follows. ${ }^{5}$

$$
y_{i t}=\delta_{C} C+\delta_{E} E+\delta_{Z} Z+\omega
$$

Finally, I report each median coefficient and its standard error, the percentage of the regressions (i.e.,

\footnotetext{
${ }^{4}$ For the UNODC and ILO datasets that are cross-sectional, I average the values of the explanatory variables for the periods of 1996-2003 and 1995-2000, respectively. For the US data with time variations, I first take the contemporary values of the explanatory variables, and one-year lagged values as for robustness check. The results are qualitatively identical.

${ }^{5}$ In this panel analysis, the lagged dependent variable is not included as an explanatory variable because the inclusion of the lagged value will absorb much of variations and therefore may undermine the explanatory power of the variables, given the binary structure of the dependent variable.
} 
$\%$ sign) in which the coefficient of the variable is statistically different from zero at the $5 \%$ level, as well as the proportion of the coefficient's cumulative distribution function that is greater or less than 0 (i.e., $\operatorname{CDF}(0)$ ). Leamer (1983) originally proposed to deem a variable as "robust" if both the lower and upper extreme bounds ${ }^{6}$ for the coefficient of the variable in $E$ have the same sign. However, Sala-i-Martin (1997) argues that this criterion is too strict, insofar that most variables would not survive such extreme bound tests. Instead, he recommends a procedure analyzing the entire distribution of the coefficient (for more detailed discussions on this method, see Sala-i-Martin (1997)). Following Sala-i-Martin, I take a $\operatorname{CDF}(0)$ value of $0.90-$ significance at the $10 \%$ level-as the threshold for a variable to be considered as "robust".

To identify push factors in countries of origin, I ran 543,150 regressions, while 406,159 regressions are run to estimate pull factors in countries of destination. Following these steps, I then compare the robustness of push and pull factors in each of the three estimation models using the UNODC, ILO and US data, respectively. Finally, I test for the robustness of the findings through two different approaches. First, I re-run the regressions excluding Organisation for Economic Cooperation and Development (OECD) members in order to find out whether the main results are solely driven by developed countries. Second, I apply a regional jackknife method, omitting one continent in each regression, checking whether one specific continent drives all the results. In total, I test seven sub-group samples by running more than one million regressions additionally. The results show that the main findingswhich are presented in Section 5 below-are neither driven by any specific continent, nor the developed world alone. ${ }^{7}$

\section{Results}

\subsection{Push Factors}

In order to identify push factors of human trafficking in countries of origin, I test for the robustness of each of the 70 variables suggested in the literature. Through the first step of employing the UNODC data as the dependent variable, 35 variables are identified as "robust", with a $\operatorname{CDF}(0)$ value of 0.90 or higher-significance at

\footnotetext{
${ }^{6}$ The lower extreme bound is defined as the lowest value for the coefficient minus two standard deviations, and the upper extreme bound is defined as the highest value for the coefficient plus two standard deviations (Sala-i-Martin, 1997).

${ }^{7}$ The regression results of sub-group testing are not presented in this paper due to the limitation of space, but can be obtained by the author upon request.
}

the $10 \%$ level. In the second step of checking for robustness by using the ILO and US data, only six of the 35 variables are confirmed to be robust in all of the estimation models. Additionally, seven variables turn out to be robust in two out of the three models. This analysis covers up to 151 countries for the period of 1996 2003 (UNODC data, 151 countries), 1995-2000 (ILO data, 63 countries), and 2000-2010 (US data, 140 countries). Table 1 shows the results regarding these robust variables. Statistics provided in the table are based on results by ordered probit regressions using the UNODC data. In addition, marginal effects are estimated by OLS methods for the simplicity of interpretation.

The most robust push factors, which turn out to be significant in all of the three models are: (log) GDP per capita (negative); the share of the food, beverage, and tobacco industries in GDP (negative); fertility rates (negative); information flows (positive)-i.e., percentage of internet users, TV, and trade in newspapers; a dummy representing a transitional economy (positive); and percentage of Muslims in the total population (negative).

In line with the migration literature, poorer countries tend to send more human trafficking victims. The significant impact of income implies the migratory motivation of victims for economic reasons. Quantitatively, the marginal effects that are calculated by OLS estimation show that an increase in GDP pc by $10 \%$-points reduces human trafficking outflows by $2 \%$ (i.e., 0.12 points on the $0-5$ scale). The result also shows that an increase in information flows by 10 points (on the 0 100 scale) increases in human trafficking outflows by $3 \%$. The positive impact of information flows ${ }^{8}$ indicates that more exposure to outside information tends to encourage people to migrate and therefore increases the pool of potential victims of human trafficking. ${ }^{9}$

The share of the food, beverage, and tobacco industries in GDP has a constraining effect on human trafficking outflows. This variable is associated with demand for low skill labor in a country; having a large industry in this field is likely to create more jobs for people who may have taken dubious migration opportunities, otherwise.

\footnotetext{
8 On the contrary, Mahmoud and Trebesch (2010) and Mo (2011) find a constraining impact of TV and phone usage on human trafficking outflows in five Eastern European countries and Nepal, respectively.

${ }^{9}$ On the other hand, migration outflows, proxied with net migration and emigration rates of the tertiary educated, do not turn out to be significant. Noting that the two available indicators of migration outflows used here may not correctly reflect total migration outflows, a linkage between migration and human trafficking outflows needs to be further investigated by using more precise measurements once they become available.
} 
Table 1. Robust push factors.

\begin{tabular}{|c|c|c|c|c|c|}
\hline \multirow{2}{*}{$\begin{array}{l}\text { Estimation Method } \\
\text { Variable }\end{array}$} & \multicolumn{4}{|c|}{ Ordered Probit } & \multirow{2}{*}{$\begin{array}{c}\text { OLS } \\
\text { Marginal } \\
\text { Effects }\end{array}$} \\
\hline & Average Beta & $\begin{array}{l}\text { Average } \\
\text { Std. Error }\end{array}$ & \% Sign & CDF-U & \\
\hline (log) GDP pc. & -2.138 & 0.379 & 0.990 & 0.999 & -1.199 \\
\hline Information flows & 0.039 & 0.014 & 0.724 & 0.964 & 0.023 \\
\hline Transition economy & 1.675 & 6.029 & 0.953 & 0.987 & 1.571 \\
\hline Muslim share & -0.008 & 0.003 & 0.681 & 0.961 & -0.011 \\
\hline Fertility rate & -0.610 & 0.138 & 0.979 & 0.998 & -0.045 \\
\hline Food, beverage and tobacco industries & -0.033 & 0.011 & 0.975 & 0.996 & -0.044 \\
\hline Rule of law & -0.381 & 0.247 & 0.398 & 0.916 & -0.589 \\
\hline Control of corruption & -0.522 & 0.238 & 0.629 & 0.961 & -0.238 \\
\hline Infant mortality rate & -0.016 & 0.008 & 0.617 & 0.922 & -0.002 \\
\hline Share of age group $0-14$ in population & -0.089 & 0.023 & 0.898 & 0.986 & -0.065 \\
\hline Crime rate & 0.042 & 0.039 & 0.190 & 0.901 & 0.025 \\
\hline Europe and Central Asia & 0.865 & 6.023 & 0.760 & 0.955 & 0.465 \\
\hline North Africa and Middle East & -1.014 & 0.418 & 0.684 & 0.960 & -0.364 \\
\hline
\end{tabular}

Note: Statistics presented in this table are based on the ordered probit estimation results using the UNODC data. In addition to that, the marginal effects were calculated by OLS. The coefficients of the first three variables are significant in all of the three models (UNODC, ILO, and US). The coefficients of the latter ten variables are significant in two of the three models (i.e. UNODC and one additional model-either ILO or US). The base variable is (log) GDP pc. The threshold to consider a variable robust is 0.9.

Increasing the share of these industries in GDP by $10 \%$-points decreases human trafficking outflows by $7.3 \%$ (i.e., 0.44 points on the $0-5$ scale). ${ }^{10}$ Also, similar to Akee et al. (2010), being a transitional economy increases human trafficking by $26 \%$. This finding is sensible given that countries under transition may not provide secure livelihoods for their citizens, and therefore people tend to seek migration options outside. This is particularly true for Eastern European countries which have experienced political and economic crises after the collapse of the communist regimes in the late 1980s, while, at the same time, having become more exposed to Western Europe-a popular destination of migration and human trafficking.

An interpretation of the negative sign for fertility rates is tricky, however. One may surmise that high fertility rates are usually associated with overpopulation and underdevelopment, pushing people to pursue risky migration options, therefore making it more likely to be victims of human trafficking. However, the result shows the opposite, indicating that higher fertility rates tend to decrease human trafficking in countries of origin (i.e. an increase in fertility rates by $10 \%$-points reduces human trafficking by $8.3 \%$ ). One possible interpretation is that higher fertility rates are associated with a more conservative attitude towards women's role in society, therefore decreasing women's mobility and aspiration for migration. This interpretation is plausible, given that many of the major origin countries are not necessarily

10 The data on the share of the food, beverage, and tobacco industries in GDP includes 112 countries, thus approximately $25 \%$ of the total observations ( 151 countries) is missing. About half of the missing values (19) come from Sub-Saharan African countries, while in other regions missing values are less than $10 \%$ of the total observations. Given that, one should interpret the result with caution for Africa. the most oppressive countries towards women, and the level of female education and labor participation is not very low in many origin countries - for instance in Eastern European and several Latin American countries. Also, the negative impact of a high Muslim population supports this interpretation. The result implies that female mobility is discouraged in Islamic countries which have presumably more conservative attitudes towards women and very low female economic participation (Cooray \& Potrafke, 2011). Quantitatively, an increase in the share of Muslims in population by $10 \%$-points reduces human trafficking outflows by almost $1.7 \%$.

Other factors which are significant in two of the three models are: rule of law (negative); control of corruption (negative); crime rates (positive); infant mortality rates (negative); the share of age group 0-14 in population (negative); being an Eastern European country (positive); being a Middle East/North African country (negative).

My results indicate that poor institutions are a push factor of human trafficking, while the previous literature shows mixed results with respect to the impact of institution (see Appendix B). Indeed, weak institutions and poor governance are detrimental to the well-being of people, and therefore push people to take risky migration options. Quantitatively, an increase in the rule of law by one point on the -2.69 to +2.12 scale decreases human trafficking outflows by almost $10 \%$, while an increase in the control of corruption by one point on the 2.22 to +2.62 scale reduces human trafficking by $4 \%$.

Also, the prevalence of general crimes is positively associated with human trafficking, i.e., an increase in total crime rates by $10 \%$-points increases human trafficking by almost $4.2 \%{ }^{11}$ This finding supports the

11 The number of countries covered in the crime rates are 104, loosing approximately $30 \%$ of the total observations (151 coun- 
crime aspect of human trafficking, which the current literature has not empirically shown-except the study by Clawson and Layne (2007) on human trafficking flows into the United States.

The results also indicate that socio-economic environments also make people more vulnerable to human trafficking. As mentioned earlier, income, employment opportunities, and the stability of economy affect human trafficking outflows. However, the relationship between the vulnerability of people and the prevalence of human trafficking outflows is less clear. Women's education and employment (or any other gender-related indicators used) do not have a significant effect in determining human trafficking outflows, similar to the mixed findings in the literature (see Appendix B). On the other hand, the percentage of people under 14 decreases human trafficking outflows, i.e., increasing the proportion of people in this age group by $10 \%$-points reduces human trafficking outflows by $10.8 \% .^{12}$ It is possibly because having many children restrains women's migratory motives, similar to the negative effect of fertility rates above. These findings suggest that women's rights have a complex relationship with human trafficking; i.e., gender discrimination does not necessarily increase human trafficking outflows, possibly because oppression against women also constraints women's mobility. Additionally, infant mortality rates-a basic indicator measuring fundamental well-being - turn out to have negative impact (similar to the finding of Mahmoud and Trebesch (2010)) but the magnitude of the effect is not practically largeincreasing the mortality rates by $10 \%$-points reduces human trafficking by $0.3 \%$.

In addition to this, economic inequality, measured by the GINI index, does not turn out to have a significant impact, although the literature (Clawson \& Layne, 2007; Jac-Kucharski, 2012; Mo, 2011) emphasizes inequality as an important cause of human trafficking outflows. However, the $\operatorname{CDF}(0)$ lies between 0.85 and 0.88 -marginally insignificant-and this result may have been driven by many missing observations (about the one third of observations are missing when including the GINI index in regressions). Thus, one should be cautious in interpreting this implication, with further investigation needed.

Lastly, the results also suggest that geographical locations influence human trafficking outflows. Being an Eastern European country, proximate to affluent Western Europe, increases the outward prevalence of human trafficking by $7.8 \%$, while being in the Middle East/North Africa reduces human trafficking by $6 \%$.

tries). Most missing values (28 countries) come from SubSaharan African countries and thus it might be possible that the result is driven by selection biases in this region. Except Africa, the data of other regions are mostly balanced with less than $10 \%$ of the total observations being lost.

12 On the other hand, Bales (2007) and Mahmoud and Trebesch (2010) find a positive effect of young populations.

\subsection{Pull Factors}

Turning to pull factors determining human trafficking flows into destination countries, I test for the robustness of 63 potential factors suggested in the literature. This analysis covers up to 153 countries for the period of 1996-2003 (UNODC data, 153 countries), 1995-2000 (ILO data, 63 countries), and 2000-2010 (US data, 141 countries). In the first step of testing with the UNODC data, 26 variables are identified as "robust" with a $\operatorname{CDF}(0)$ value of 0.90 or higher-significance at the $10 \%$ level. In the second step of using the ILO and US data, only three factors turn out to be robust in all of the models: (log) GDP per capita (positive); language fraction (positive); and information flows (negative). Table 2 shows the results of these robust pull factors. Statistics presented in the table are provided by the results of ordered probit regressions employing the UNODC data, except the marginal effects calculated by OLS.

Alongside the migration literature, wealthier countries receive more human trafficking victims. Increasing income by $10 \%$-points increases human trafficking inflows by $7.8 \%$ (i.e. 0.47 points on the $0-5$ scale). Interestingly, information flows have a constraining effect in destination countries, opposite to a push effect found in origin countries. An increase in information flows by 10 points (on the $0-100$ scale) reduces human trafficking by almost $2 \%$. It could be possible that information increases public awareness towards human trafficking problems in destination countries, while exposure to information in origin countries has an opposite effect by motivating people to move elsewhere. In line with the findings of Akee et al. (2010), more linguistically divided countries tend to induce more human trafficking flows, possibly because having many minorities in a country may create markets for informal, exploitative, and low-paid labor, where victims of human trafficking are typically employed. Quantitatively, an increase in language fraction by 0.1 point (on the 0 to 1 scale) increases human trafficking by $2.3 \%$.

In addition to the three factors above, 10 variables turn out to have significant effects in two of the three models; the percentage of the workforce employed in agriculture (positive); refugee inflows (positive); (log) population size (positive); international tourist inflows (positive); crime rates (positive); (log) amount of heroin seized (positive) $^{13}$; OECD membership (positive); being an East Asian country (positive); being a land-locked country (negative); and the share of Catholics in population (negative).

\footnotetext{
13 The data on crime rates cover 105 countries, losing approximately $30 \%$ of the total observations, due to many missing values in Sub-Saharan African countries. However, the heroin data, another crime indicator, covers 145 countries and missing values are less than $10 \%$ in the African as well as the other regions. The positive impact of both variables indicates that the finding of the crime aspect of human trafficking is less likely driven by selection biases.
} 
Table 2. Robust pull factors.

\begin{tabular}{|c|c|c|c|c|c|}
\hline \multirow{2}{*}{$\begin{array}{l}\text { Estimation Method } \\
\text { Variable }\end{array}$} & \multicolumn{4}{|c|}{ Ordered probit } & \multirow{2}{*}{$\begin{array}{c}\text { OLS } \\
\text { Marginal } \\
\text { Effects }\end{array}$} \\
\hline & $\begin{array}{c}\text { Average } \\
\text { Beta }\end{array}$ & $\begin{array}{l}\text { Average } \\
\text { Std. Error }\end{array}$ & \% Sign & CDF-U & \\
\hline (log) GDP pc. & 1.147 & 0.289 & 0.970 & 0.999 & 4.728 \\
\hline Information flows & -0.019 & 0.011 & 0.336 & 0.919 & -0.011 \\
\hline Language fractionalization & 1.281 & 0.436 & 0.949 & 0.994 & 1.378 \\
\hline$\%$ of workforce in agriculture & 0.024 & 0.010 & 0.772 & 0.981 & 0.021 \\
\hline Refugees & $8.763 e-07$ & $4.708 \mathrm{e}-07$ & 0.608 & 0.941 & $2.110 \mathrm{e}-07$ \\
\hline (log) Population & 0.334 & 0.080 & 0.996 & 0.999 & 0.330 \\
\hline International tourism & $3.094 \mathrm{e}-08$ & $1.200 \mathrm{e}-08$ & 0.801 & 0.975 & $1.664 \mathrm{e}-08$ \\
\hline Crime rate & 0.173 & 0.61 & 0.864 & 0.977 & 0.037 \\
\hline (log) Amount of heroin seized & 0.001 & 0.00005 & 0.792 & 0.978 & 0.28 \\
\hline OECD membership & 0.729 & 0.354 & 0.519 & 0.954 & 0.271 \\
\hline East Asia and Pacific & 0.640 & 0.362 & 0.354 & 0.932 & 0.177 \\
\hline Landlocked country & -0.421 & 0.256 & 0.267 & 0.926 & -0.616 \\
\hline Share of Catholic in population & -0.007 & 0.003 & 0.772 & 0.979 & -0.007 \\
\hline
\end{tabular}

Note: Statistics presented in this table are based on the ordered probit estimation results using the UNODC data. In addition to that, the marginal effects were calculated by OLS. The coefficients of the first three variables are significant in all of the three models (UNODC, ILO, and US). The coefficients of the latter ten variables are significant in two of the three models (i.e. UNODC and one additional model-either ILO or US). The base variable is (log) GDP pc. The threshold to consider a variable robust is 0.9.

The results show that the size of the agricultural sector, proxied by the percentage of the workforce employed in agriculture, turns out to increase human trafficking inflows. An increase in the size of the agricultural sector by $10 \%$-points increases in human trafficking inflows by $3.3 \%$. Given that a considerable portion of trafficking victims is exploited in agricultural fields in destination countries, this result indicates that demand for labor in agriculture determines the level of human trafficking inflows. On the other hand, other developmental indicators such as gender equality, and health and environmental quality measures, do not seem to have any significant impact on human trafficking in destination countries. In fact, it is more difficult to build a convincing hypothesis regarding relationship between gender discrimination and human trafficking in destination countries. Cho (2013) points out that, as the majority of trafficking victims are foreigners, a high level of women's rights in a destination country is at best irrelevant, or even induces more human trafficking flows. The reason for such a controversial argument is that victims of trafficking are usually exploited in sex industries or domestic labor markets where local women in destination countries are less willing to work once they have a high level of education and opportunities.

Interestingly, law enforcement and institutional quality do not play an important role in determining human trafficking flows into destination countries, different from the results of origin countries. From these results, one can surmise that anti-trafficking measures are still not well-grounded in general law and enforcement and/or anti-trafficking is not necessarily a policy priority in many destination countries-even in countries with a high level of rule and order.

Turning to the crime aspect, the results strongly suggest that the prevalence of crime in general and organized crime-the latter proxied by the amount of heroin seized-affect the prevalence of human trafficking. An increase in total crime rates by $10 \%$-points increases human trafficking inflows by almost $6.2 \%$, while an increase in the amount of heroin seized $(\mathrm{kg})$ by the same percentage increases human trafficking inflows by $0.5 \%$. Distinguished from the literature so far, my study empirically shows that the crime aspect of human trafficking is evident both in origin and destination countries. This finding implies that human trafficking is not merely an accompanying phenomenon of human movements, but is caused by environments where criminal activities are prevailing.

As human trafficking is mainly a transnational human transaction between the developing and developed world, belonging to the developed world (OECD membership) increases human trafficking inflows by $4.5 \%$. Similar to origin countries, geography and culture also matter in destination countries. East Asia tends to receive more human trafficking inflows, i.e. being in East Asia increases the inflows by $3 \%$, while being a land-locked country reduces human trafficking by almost $10 \%$. While the Muslim culture has a constraining effect in origin countries, the Catholicism reduces human trafficking in destination countries-i.e., an increase in the share of Catholics in population by $10 \%$ points decreases human trafficking by about $1.2 \%$. Additionally, certain types of human flows into countries-i.e. refugee and tourist inflows-, as well as population sizes, increase human trafficking inflows, but their magnitudes are rather trivial.

\section{Conclusion}

In this study, I empirically investigated robust push and pull factors of human trafficking by exploring a large set of variables suggested in the literature. Overall, my findings suggest that the crime pillar most robustly explains 
human trafficking, among the four pillars discussed above. It signals to policy makers that human trafficking should not be overlooked just as a side effect of migration, and urges them to adopt criminal justice and crime prevention measures against human trafficking.

Also, several factors reflecting the other three pillars turn out to have significant effects on human trafficking. The robust impact of income level both in origin and destination countries indicates that human trafficking is largely a phenomenon related to economic migration. Institutional quality seems to matter more for countries of origin but not necessarily for destination countries. Vulnerability does not have a straightforward relationship with human trafficking. Indeed, a high level of gender inequality and underdevelopment may even reduce human trafficking, arguably by constraining human mobility. Rather than developmental indicators, employment structures and demand for certain types of labor seem to explain the prevalence of human trafficking. Also, the geographic and cultural characteristics of countries matter for human trafficking in-/outflows.

On the other hand, many factors suggested as plausible causes of human trafficking in the literature do not turn out to be robust determinants in my analysis. However, this does not necessarily lead to the conclusion that such factors do not influence human trafficking at all. While the factors found to be robust in my investigation tend to have exclusive explanatory power on the prevalence of human trafficking, other factors may affect human trafficking via indirect linkage or interacting with some other factors.

In fact, my study does not claim to provide a final conclusion on the determinants of human trafficking but rather acknowledges that human trafficking is a complex phenomenon in which many factors are interlinked. This observation calls for further studies in many different aspects, and, in particular, a complex relationship between gender discrimination and human trafficking warrants a closer look.

\section{Acknowledgments}

The author cordially acknowledges the generous funding provided by the European Commission. The author thanks the participants of the Workshop on Human Trafficking, International Crime, and National Security: A Human Rights Perspective (2012, Goettingen) for excellent feedbacks and discussions.

\section{Conflict of Interests}

The author declares no conflict of interests.

\section{References}

Akee, R., Basu, A., Chau, N., \& Khamis, M. (2010). Eth- nic Fragmentation, Conflict, Displaced Persons and Human Trafficking: An Empirical Analysis. In G. S. Epstein \& I. N. Gang (Eds.), Migration and Culture: Frontiers of Economics and Globalization (Vol. 8, pp. 691-716). Bingley, UK: Emerald Group Publishing.

Akee, R., Bedi, A., Basu, A., \& Chau, N. (2014). Transnational trafficking, law enforcement and victim protection: A middleman's perspective. Journal of Law and Economics, 57, 349-386.

Akee, R., Basu, A., Chau, N., \& Khamis, M. (2012). Vulnerability and Trafficking. Mimeo: Wesleyan University.

Alesina, A., Devleeschauwer, A., Easterly, W., Kurlat, S., \& Wacziarg, R. (2003). Fractionalization. Journal of Economic Growth, 8, 155-194.

Aronowitz, A. (2001). Smuggling and trafficking in human beings: The phenomenon, the markets that drive it and the organization that promote it. European Journal on Criminal Policy and Research, 9, 163-195.

Bales, K. (2007). What predicts human trafficking? International Journal of Comparative and Applied Criminal Justice, 31, 269-279.

Beck, T., Clarke, G., Groff, A., Keefer, P., \& Walsh, P. (2001). New tools in comparative political economy: The database of political institutions. World Bank Economic Review, 15, 165-176.

Belser, P. (2005). Forced Labor and Human Trafficking: Estimating the Profits (ILO WP No. 42). Geneva: Switzerland.

Bettio, F., \& Nandi, T. (2010). Evidence on women trafficked for sexual exploitation: A rights-based analysis. European Journal of Law and Economics, 29, 1542.

Cameron, S., \& Newman, E. (2008). Trafficking in Humans: Structural Factors. In S. Cameron \& E. Newman (Eds.), Trafficking in Humans: Social, Cultural and Political Dimensions. New York: United Nations University Press.

Cheibub, J., Gandhi, J., \& Vreeland, J. (2010). Democracy and dictatorship revisited. Public Choice, 143, 67101.

Cho, S.-Y. (2013). Integrating equality: Globalization, women's rights, and human Trafficking. International Studies Quarterly, 57, 683-697.

Cho, S.-Y., Dreher, A., \& Neumayer, E. (2013). Does legalized prostitution increase human trafficking? World Development, 41, 67-82.

Cho, S.-Y., Dreher, A., \& Neumayer, E. (2014). The determinants of anti-trafficking policies: Evidence from a new index. Scandinavian Journal of Economics, 116, 429-454.

Cho, S.-Y., \& Vadlamannati, K. C. (2012). Compliance with the Anti-Trafficking Protocol. European Journal of Political Economy, 28, 249-265.

Cingranelli, D., \& Richards, D. (2010). The CingranelliRichards (CIRI) Human Rights Data Project. Human 
Rights Quarterly, 32, 395-418.

Clawson, H., \& Layne, M. (2007). Estimating Human Trafficking into the United States: Development of a Methodology. Washington, D.C.: ICF International.

Cooray, A., \& Potrafke, N. (2011). Gender inequality in education: Political institutions or culture and religion? European Journal of Political Economy, 27, 268-280.

Danailova-Trainor, G., \& Belser, P. (2006). Globalization and the Illicit Market for Human Trafficking: an Empirical Analysis of Supply and Demand (ILO WP No. 78). Geneva, Switzerland: ILO.

Di Tommaso, M., Shima, I., Strøm, S., \& Bettio, F. (2009). As bad as it gets: Well-being deprivation of sexually exploited trafficked women. European Journal of Political Economy, 25, 143-162.

Dreher, A. (2006). Does globalization affect growth? Empirical evidence from a new index. Applied Economics, 38, 1091-1110.

Encyclopedia Britannica. (2001). Book of the Year. Chicago: Encyclopedia Britannica.

European Commission. (2013). Trafficking in Human Beings (EuroStat Methodologies and Working Paper). Brussels, Belgium: European Commission.

Frank, R. (2011). The Political Economy of Human Trafficking. Mimeo: University of New Orleans.

Freedom House. (2010). Freedom of the press. Retrieved from: www.freedomhouse.org

Harrendorf, S., Heiskanen, M., \& Malby, S. (2010). International Statistics on Crime and Justice (Working paper). Helsinki: European Institute for Crime Prevention and Control and United Nations Office on Drugs and Crime.

Hegre, H., \& Sambanis, N. (2006). Sensitivity analysis of empirical results on civil war onset. Journal of Conflict Resolution, 50, 508-535.

International Country Risk Guide. (2009). Political risk data. PRS Group. Retrieved from www.prsgroup.com

International Labor Organization (ILO). (2005). Database in Global Reports. Geneva, Switzerland: ILO.

International Labor Organization (ILO). (n.d.). Thesaurus. Retrieved from www.ilo.org/thesaurus

International Organization for Migration (IOM). (2012). Counter Trafficking Module. Geneva, Switzerland: IOM.

Interpol. (2009). Retrieved from www.interpol.int/ Public/THB

Jac-Kucharski, A. (2012). The determinants of human trafficking: A US case study. International Migration, 50, 150-165.

Jakobsson, N., \& Kotsadam, A. (2013). The law and economics of international sex slavery: Prostitution law and trafficking for sexual exploitation. European Journal of Law and Economics, 35, 87-107.

Kangaspunta, K. (2003). Mapping the inhuman trade: preliminary findings of the database on trafficking in human beings. Forum on Crime and Society, 3,
81-103.

Kaufmann, D., Kraay, A., \& Mastruzzi, M. (2009). Governance Matters VIII: Aggregate and Individual Governance Indicators 1996-2008 (World Bank Policy Research WP No. 4978). Washington, D.C.: World Bank.

La Porta, R., Lopez-de-Silanes, F., Shleifer, A., \& Vishny, R. 1998. Law and finance. Journal of Political Economy, 106, 1113-1155.

Leamer, E. (1983). Let's take the con out of econometrics. American Economic Review, 73, 31-43.

Levine, R., Renelt, D. (1992). A sensitivity analysis of cross-country growth regressions. American Economic Review, 82, 942-963.

Mahmoud, T. O, \& Trebesch, C. (2010). The economic drivers of human trafficking: Micro-evidence from five Eastern European countries. Journal of Comparative Economics, 38, 173-188.

Marshall, M., Gurr, T., \& Jaggers, K. (2014). Polity IV Project: Political Regime Characteristics and Transitions, 1800-2013. Vienna: Center for Systemic Peace.

Mayer, T., \& Zignago, S. (2011). Notes on CEPII's Distances Measures: The GeoDist Database (CEPII WP No. 25). Paris, France: CEPII.

Mo, C. (2011). Perceived Relative Poverty and Risk: An Aspiration-Based Model of Vulnerability. Mimeo: Stanford University.

Neumayer, E. (2006). Unequal access to foreign spaces: How states use visa restrictions to regulate mobility in a globalised world. Transactions of the British Institute of Geographers, 31, 72-84.

Neumayer, E., \& Perkins, R. (2008). Extra-territorial interventions in conflict spaces: Explaining the geographies of post-cold war peacekeeping. Political Geography, 27, 895-914.

Organisation for Economic Co-operation and Development (OECD). (2011). Transition economy and OECD membership. Retrieved from www.oecd.org

Potrafke, N. (2013). Human Anti-trafficking Policies: The Roles of Religion and Political Institutions (CESifo WP No. 4278). Munich: CESifo.

Rao, S., Christina, P. (2012). Understanding human trafficking origin: A cross-country empirical analysis. Feminist Economics, 18, 231-263.

Sala-i-Martin, X. (1997). I just ran two million regressions. American Economic Review, 87, 178-183.

Smith, C., \& Smith, H. (2010). Human trafficking: The unintended effects of United Nations intervention. International Political Science Review, 32, 125-145.

Transparency International. (2010). Corruption Perception Index. Retrieved from www.transparency.de

United Nations (UN). (2000). Convention against Transnational Organized Crime and Its Protocol to Prevent, Suppress and Punish Trafficking in Persons, especially Women and Children. New York: UN.

United Nations (UN). 2008. Surveys on Crime Trends 
and the Operations of Criminal Justice Systems (CTS). Vienna: UN.

United Nations Office on Drugs and Crime (UNODC). 2006. Global Report on Trafficking in Persons. Vienna: UN.

United Nations Office on Drugs and Crime (UNODC). 2008. An Introduction to Human Trafficking: Vulnerability, Impact and Action. Vienna: UN.

United States Department of State. (2001-2014). Trafficking in Persons Report. Washington, D.C.: United States Department of State Publication.
Van Dijk, J. (2008). The World of Crime: Breaking the Silence of Problems of Security, Justice, and Development across the World. Los Angeles: Sage Publication.

World Bank. (2011). World development indicators. Retrieved from www.worldbank.org

Zhang, S., Finch, B., \& Qin, Y. (2011). Measuring Labor Trafficking with Respondent Driven Sampling: Findings from a U.S. Study. Mimeo: San Diego State University.

\section{About the Author}

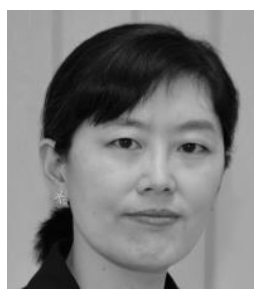

\section{Dr. Seo-Young Cho}

Seo-Young Cho is Junior Professor of Economics and Head of the Empirical Institutional Economics research group at the University of Marburg in Germany. Her research fields include institutional economics, the economics of crime, and gender economics with a particular focus on human trafficking, prostitution, organized crimes, gender equality, and migration. Also, she is the author of the 3P Antitrafficking Policy Index measuring the institutional efforts of combating human trafficking. 


\section{Appendices}

Appendix A. Global datasets on human trafficking.

\begin{tabular}{|c|c|c|c|c|}
\hline Data & Measurement & Countries covered & Years covered & Source \\
\hline $\begin{array}{l}\text { UNODC Incidence of } \\
\text { Reporting Index } \\
\text { (origin, transit, and } \\
\text { destination) }\end{array}$ & $\begin{array}{l}6 \text { scales: } 0 \text { (no reported } \\
\text { flow)-5 (very high flow) }\end{array}$ & 161 countries & $\begin{array}{l}1996-2003 \\
\text { (cross-sectional) }\end{array}$ & UNODC (2006) \\
\hline $\begin{array}{l}\text { ILO Global Report } \\
\text { Data (in-/outflows) }\end{array}$ & $\begin{array}{l}\text { Number of cases human } \\
\text { trafficking in-/outflows re- } \\
\text { ported in the ILO global } \\
\text { dataset }\end{array}$ & 74 countries & $\begin{array}{l}\text { 1995-2000 } \\
\text { (cross-sectional) }\end{array}$ & Belser et al. (2005) \\
\hline $\begin{array}{l}\text { US Trafficking in Per- } \\
\text { sons Data } \\
\text { (origin and destina- } \\
\text { tion) }\end{array}$ & $\begin{array}{l}\text { Dummy variable: } 1 \text { if the } \\
\text { reported cases are } 100 \text { or } \\
\text { higher in a given year in a } \\
\text { given country; } 0 \text {, otherwise }\end{array}$ & Max. 190 countries & $\begin{array}{l}2000-2010 \\
\text { (panel) }\end{array}$ & $\begin{array}{l}\text { United States De- } \\
\text { partment of State } \\
(2001-2014)\end{array}$ \\
\hline
\end{tabular}

A.1. Definition of Human Trafficking

\section{UNODC Incidence of Reporting Index}

"Trafficking in persons shall mean the recruitment, transportation, transfer, harboring or receipt of persons, by means of the threat or use of force or other forms of coercion, of abduction, of fraud, of deception, of the abuse of power or of a position of vulnerability or of the giving or receiving of payments or benefits to achieve the consent of a person having control over another person, for the purpose of exploitation. Exploitation shall include, at a minimum, the exploitation of the prostitution of others or other forms of sexual exploitation, forced labor or service, slavery or practices similar to slavery, servitude or the removal of organs." (UN, 2000, article 3)

\section{ILO Global Report Data}

"Recruitment, transportation, transfer, harbouring or receipt of persons by means of the threat or use of force or other forms of coercion, of abduction, of fraud, of deception, of the abuse of power or of a position of vulnerability or of the giving or receiving of payments or benefits to achieve the consent of a person having control over another person, for the purpose of exploitation." (ILO, n.d.)

\section{US Trafficking in Persons Data}

"Trafficking in persons and human trafficking have been used as umbrella terms for the act of recruiting, harboring, transporting, providing, or obtaining a person for compelled labor or commercial sex acts through the use of force, fraud, or coercion." (United States Department of State, 2014) 
Appendix B. List of push factors examined

\begin{tabular}{|c|c|c|c|}
\hline Push Factors & Suggested by & Effects & Data \\
\hline GDP pc. & $\begin{array}{l}\text { Akee et al. (2010, 2014, 2012), Bettio } \\
\text { and Nandi (2010), Clawson and Layne } \\
\text { (2007), Danailova-Trainor and Belser } \\
\text { (2006), Di Tommaso et al. (2009), Frank } \\
\text { (2011), Jac-Kucharski (2012), Mo } \\
\text { (2011), Rao and Presenti (2012) }\end{array}$ & negative & World Bank (2011) \\
\hline Population & $\begin{array}{l}\text { Clawson and Layne (2007), Danailova- } \\
\text { Trainor and Belser (2006), Frank } \\
\text { (2011), Mo (2011), Rao and Presenti } \\
\text { (2012) }\end{array}$ & positive & World Bank (2011) \\
\hline Democracy & Frank (2011), Jac-Kucharski (2012) & positive/insignificant & $\begin{array}{l}\text { Cheibub, Gandhi and Vreeland } \\
\text { (2010), Marshall, Gurr, \& Jaggers } \\
\text { (2014) }\end{array}$ \\
\hline Control of corruption & $\begin{array}{l}\text { Bales (2007), Clawson and Layne } \\
\text { (2007), Jac-Kucharski (2012), Mahmoud } \\
\text { and Trebesch (2010), Rao and Presenti } \\
\text { (2012) }\end{array}$ & insignificant/negative & $\begin{array}{l}\text { International Country Risk Guide } \\
\text { (2009), Kaufmann, Kraay and } \\
\text { Mastruzzi (2009), Transparency } \\
\text { International (2010) }\end{array}$ \\
\hline Rule of law & $\begin{array}{l}\text { Akee et al. (2010, 2014, 2012), } \\
\text { Mahmoud and Trebesch (2010) }\end{array}$ & negative/insignificant & $\begin{array}{l}\text { International Country Risk Guide } \\
\text { (2009), Kaufmann et al. (2009) }\end{array}$ \\
\hline Political stability & Akee et al. (2014) & negative & Kaufmann et al. (2009) \\
\hline Voice and accountability & Akee et al. (2014) & insignificant & Kaufmann et al. (2009) \\
\hline External conflict & $\begin{array}{l}\text { Akee et al. (2010), Bales (2007), Frank } \\
\text { (2011), Mo (2011), Rao and Presenti } \\
\text { (2012) }\end{array}$ & negative/insignificant & $\begin{array}{l}\text { International Country Risk Guide } \\
\text { (2009) }\end{array}$ \\
\hline Internal conflict & $\begin{array}{l}\text { Akee et al. (2010), Bales (2007), Frank } \\
\text { (2011), Mo (2011), Rao and Presenti } \\
\text { (2012) }\end{array}$ & negative/insignificant & $\begin{array}{l}\text { International Country Risk Guide } \\
\text { (2009) }\end{array}$ \\
\hline Ethnic tension & Clawson and Layne (2007) & positive & $\begin{array}{l}\text { International Country Risk Guide } \\
\text { (2009) }\end{array}$ \\
\hline $\begin{array}{l}\text { Fractionalization: ethnic, } \\
\text { religious, and language ( } 3 \\
\text { variables) }\end{array}$ & Akee et al. (2010) & positive & Alesina et al. (2003) \\
\hline $\begin{array}{l}\text { Refugee and IDP } \\
\text { populations }\end{array}$ & Akee et al. (2010) & positive & World Bank (2011) \\
\hline $\begin{array}{l}\text { Transition economy } \\
\text { (dummy) }\end{array}$ & $\begin{array}{l}\text { Akee et al. (2014), Rao and Presenti } \\
\text { (2012) }\end{array}$ & positive & OECD (2011) \\
\hline $\begin{array}{l}\text { Landlocked country } \\
\text { (dummy) }\end{array}$ & Akee et al. $(2010,2014,2012)$ & negative & Mayer and Zignago (2011) \\
\hline $\begin{array}{l}\text { Female unemployment } \\
\text { rate }\end{array}$ & Danailova-Trainor and Belser (2006) & positive & World Bank (2011) \\
\hline Unemployment rate & $\begin{array}{l}\text { Clawson and Layne (2007), Jac- } \\
\text { Kucharski (2012) }\end{array}$ & positive/negative & World Bank (2011) \\
\hline $\begin{array}{l}\text { Labor force participation } \\
\text { rate }\end{array}$ & Clawson and Layne (2007) & unclear & World Bank (2011) \\
\hline $\begin{array}{l}\text { Female labor force } \\
\text { participation rate }\end{array}$ & Clawson and Layne (2007) & unclear & World Bank (2011) \\
\hline Share of rural populations & Mahmoud and Trebesch (2010) & mostly insignificant & World Bank (2011) \\
\hline Urbanization/capital & Mahmoud and Trebesch (2010) & insignificant & World Bank (2011) \\
\hline Infant mortality rate & $\begin{array}{l}\text { Bales (2007), Mahmoud and Trebesch } \\
\text { (2010) }\end{array}$ & positive/negative & World Bank (2011) \\
\hline $\begin{array}{l}\text { Physicians (per 1,000 } \\
\text { people) }\end{array}$ & Mahmoud and Trebesch (2010) & insignificant & World Bank (2011) \\
\hline Crime rate & $\begin{array}{l}\text { Bettio and Nandi (2010), Clawson and } \\
\text { Layne (2007), Mahmoud and Trebesch } \\
\text { (2010) }\end{array}$ & insignificant/positive & United Nations (2008) \\
\hline GINI index & $\begin{array}{l}\text { Clawson and Layne (2007), Jac- } \\
\text { Kucharski (2012), Mo (2011) }\end{array}$ & positive & World Bank (2011) \\
\hline $\begin{array}{l}\text { Poverty measure } \\
\text { (headcount) }\end{array}$ & Clawson and Layne (2007), Mo (2011) & positive/negative & World Bank (2011) \\
\hline
\end{tabular}




\begin{tabular}{|c|c|c|c|}
\hline Prostitution law & Akee et al. $(2010,2014)$ & mostly insignificant & Cho et al. (2013) \\
\hline $\begin{array}{l}\text { Women's economic } \\
\text { rights, social rights ( } 2 \\
\text { variables) }\end{array}$ & Clawson and Layne (2007) & negative & Cingranelli and Richards (2010) \\
\hline $\begin{array}{l}\text { Female education: female } \\
\text { literacy rate (\% of female } \\
\text { age } 15 \text { or above) }\end{array}$ & $\begin{array}{l}\text { Bettio and Nandi (2010), Di Tommaso } \\
\text { et al. (2009), Rao and Presenti (2012) }\end{array}$ & $\begin{array}{l}\text { positive/negative/insi } \\
\text { gnificant }\end{array}$ & World Bank (2011) \\
\hline $\begin{array}{l}\text { Female education: female } \\
\text { literacy rate (\% of female } \\
\text { age } 15-24)\end{array}$ & $\begin{array}{l}\text { Bettio and Nandi (2010), Di Tommaso } \\
\text { et al. (2009) }\end{array}$ & $\begin{array}{l}\text { positive/negative/insi } \\
\text { gnificant }\end{array}$ & World Bank (2011) \\
\hline $\begin{array}{l}\text { Education : literacy rate } \\
\text { (\% of people age } 15 \text { or } \\
\text { above) }\end{array}$ & $\begin{array}{l}\text { Clawson and Layne (2007), Mahmoud } \\
\text { and Trebesch (2010), Zhang et al. } \\
\text { (2011) }\end{array}$ & negative/insignificant & World Bank (2011) \\
\hline $\begin{array}{l}\text { Education: literacy rate } \\
\text { (\% of people age } 15-24 \text { ) }\end{array}$ & $\begin{array}{l}\text { Clawson and Layne (2007), Mahmoud } \\
\text { and Trebesch (2010), Zhang et al. } \\
\text { (2011) }\end{array}$ & negative/insignificant & World Bank (2011) \\
\hline $\begin{array}{l}\text { TV and phone } \\
\text { usage/information flows }\end{array}$ & $\begin{array}{l}\text { Mahmoud and Trebesch (2010), Mo } \\
\text { (2011) }\end{array}$ & negative & Dreher (2006) \\
\hline Visa restriction & Jac-Kucharski (2012) & insignificant & Neumayer (2006) \\
\hline $\begin{array}{l}\text { Number of UN } \\
\text { peacekeepers sent } \\
\text { abroad, normalized by } \\
\text { populations }\end{array}$ & Smith and Smith (2010) & positive & Dreher (2006) \\
\hline $\begin{array}{l}\text { Number of UN } \\
\text { peacekeepers residing in } \\
\text { the country, normalized } \\
\text { by populations }\end{array}$ & Smith and Smith (2010) & positive & Neumayer and Perkins (2008) \\
\hline $\begin{array}{l}\text { Food production index } \\
\text { /Share of food, beverage } \\
\text { and tobacco industries in } \\
\text { GDP ( } 2 \text { var.) }\end{array}$ & Bales (2007) & positive & World Bank (2011) \\
\hline $\begin{array}{l}\text { Grant amnesty (Anti- } \\
\text { trafficking protection } \\
\text { policy) }\end{array}$ & Akee et al. (2014) & insignificant & Cho et al. (2014) \\
\hline $\begin{array}{l}\text { OECD membership } \\
\text { (dummy) }\end{array}$ & Belser (2005) & negative & $\operatorname{OECD}(2011)$ \\
\hline $\begin{array}{l}\text { Regional dummy: East } \\
\text { Asia and Pacific, Europe } \\
\text { and Central Asia, Latin } \\
\text { America and Caribbean, } \\
\text { North Africa and Middle } \\
\text { East, North America, } \\
\text { South Asia, and Sub- } \\
\text { Saharan Africa (7 } \\
\text { variables) }\end{array}$ & $\begin{array}{l}\text { Akee et al. (2014), Rao and Presenti } \\
\text { (2012) }\end{array}$ & $\begin{array}{l}\text { positive (the } \\
\text { reference group: } \\
\text { developed country- } \\
\text { group) }\end{array}$ & World Bank (2011) \\
\hline $\begin{array}{l}\text { Share of Religion in } \\
\text { populations: Muslim, } \\
\text { Catholic, and Protestants } \\
\text { ( } 3 \text { variables) }\end{array}$ & Clawson and Layne (2007) & unclear & Encyclopedia Britannica (2001) \\
\hline $\begin{array}{l}\text { Legal origin: British, } \\
\text { socialist, French, and } \\
\text { German dummy ( } 4 \\
\text { variables) }\end{array}$ & Akee et al. (2014) & insignificant & $\begin{array}{l}\text { La Porta, Lopez-de-Silanes, } \\
\text { Shleifer, \& Vishny (1998) }\end{array}$ \\
\hline $\begin{array}{l}\text { Major language: English, } \\
\text { French, Spanish, } \\
\text { Portuguese and German } \\
\text { dummy (5 var.) }\end{array}$ & Zhang et al. (2011) & $\begin{array}{l}\text { Spanish: positive (US } \\
\text { case study) }\end{array}$ & Encyclopedia Britannica (2001) \\
\hline Emigration rates & Clawson and Layne (2007) & positive & World Bank (2011) \\
\hline Net migrants & $\begin{array}{l}\text { Clawson and Layne (2007), Mahmoud } \\
\text { and Trebesch (2010) }\end{array}$ & positive & World Bank (2011) \\
\hline
\end{tabular}




\begin{tabular}{|c|c|c|c|}
\hline $\begin{array}{l}\text { Fertility rate (number of } \\
\text { children) }\end{array}$ & Di Tommaso et al. (2009) & insignificant & World Bank (2011) \\
\hline $\begin{array}{l}\text { Share of age group } 0-14 \\
\text { in total population }\end{array}$ & $\begin{array}{l}\text { Bales (2007), Mahmoud and Trebesch } \\
\text { (2010) }\end{array}$ & positive & World Bank (2011) \\
\hline $\begin{array}{l}\text { Population density } \\
\text { (people per square } \mathrm{km} \text { of } \\
\text { land area) }\end{array}$ & Bales (2007) & positive & World Bank (2011) \\
\hline Consumer price index & Clawson and Layne (2007) & positive & World Bank (2011) \\
\hline Amount of heroin seized & Clawson and Layne (2007) & positive & United Nations (2008) \\
\hline $\begin{array}{l}\text { Human rights index: } \\
\text { physical integrity }\end{array}$ & Clawson and Layne (2007) & positive & Cingranelli and Richards (2010) \\
\hline CO2 Emissions & Clawson and Layne (2007) & positive & World Bank (2011) \\
\hline
\end{tabular}


Appendix C. List of pull factors examined.

\begin{tabular}{|c|c|c|c|}
\hline Pull Factors & Suggested by & Effects & Data sources \\
\hline GDP pc. & $\begin{array}{l}\text { Akee et al. (2010, 2012, 2014), Cho (2013), } \\
\text { Cho et al. (2013), Frank (2011), Jakobsson } \\
\text { and Kotsadam (2013) }\end{array}$ & positive & World Bank (2011) \\
\hline Population & $\begin{array}{l}\text { Cho (2013), Cho et al. (2013), Frank (2011), } \\
\text { Jakobsson and Kotsadam (2013) }\end{array}$ & $\begin{array}{l}\text { mostly positive (Frank } \\
2011 \text {, insignificant) }\end{array}$ & World Bank (2011) \\
\hline Democracy & Cho et al. (2013), Frank (2011) & negative/positive & $\begin{array}{l}\text { Cheibub et al. (2010), Marshall et } \\
\text { al. (2014) }\end{array}$ \\
\hline Control of corruption & Bales (2007), Cho (2013) & negative & $\begin{array}{l}\text { International Country Risk Guide } \\
\text { (2009), Kaufmann et al. (2009), } \\
\text { Transparency International } \\
\text { (2010) }\end{array}$ \\
\hline Rule of law & $\begin{array}{l}\text { Akee et al. (2010, 2012, 2014), Cho et al. } \\
\text { (2013), Jakobsson and Kotsadam (2013) }\end{array}$ & insignificant/negative & $\begin{array}{l}\text { International Country Risk Guide } \\
\text { (2009), Kaufmann et al. (2009) }\end{array}$ \\
\hline Political stability & Akee et al. (2014) & negative & Kaufmann et al. (2009) \\
\hline $\begin{array}{l}\text { Voice and } \\
\text { accountability }\end{array}$ & Akee et al. (2014) & insignificant & Kaufmann et al. (2009) \\
\hline External conflict & Akee et al. (2010), Frank (2011) & positive & $\begin{array}{l}\text { International Country Risk Guide } \\
\text { (2009) }\end{array}$ \\
\hline Internal conflict & Akee et al. (2010), Frank (2011) & positive & $\begin{array}{l}\text { International Country Risk Guide } \\
\text { (2009) }\end{array}$ \\
\hline Ethnic tension & Akee et al. (2010) & positive & $\begin{array}{l}\text { International Country Risk Guide } \\
\text { (2009) }\end{array}$ \\
\hline $\begin{array}{l}\text { Fractionalization: } \\
\text { ethnic, religious, and } \\
\text { language ( } 3 \text { variables) }\end{array}$ & Akee et al. (2010) & positive & Alesina et al. (2003) \\
\hline Leftwing executive & Cho et al. (2013) & insignificant & Beck et al. (2001) \\
\hline Rightwing executive & Cho et al. (2013) & insignificant & Beck et al. (2001) \\
\hline Media freedom & Cho et al. (2013) & insignificant & Freedom House (2010) \\
\hline $\begin{array}{l}\text { Prostitution law } \\
\text { (legalization) }\end{array}$ & $\begin{array}{l}\text { Akee et al. (2010, 2014), Cho et al. (2013), } \\
\text { Jakobsson and Kotsadam (2013) }\end{array}$ & Insignificant/positive & Cho et al. (2013) \\
\hline $\begin{array}{l}\text { Amount of heroin } \\
\text { seized }\end{array}$ & Jakobsson and Kotsadam (2013) & insignificant & United Nations (2008) \\
\hline $\begin{array}{l}\text { Women's economic } \\
\text { rights, social rights ( } 2 \\
\text { variables) }\end{array}$ & Cho (2013) & insignificant & Cingranelli and Richards (2010) \\
\hline $\begin{array}{l}\text { Social globalization } \\
\text { (incl. information } \\
\text { flows) }\end{array}$ & Cho (2013) & insignificant/mixed & Dreher (2006) \\
\hline Unemployment rate & Cho et al. (2013) & insignificant & World Bank (2011) \\
\hline $\begin{array}{l}\% \text { of workforce in } \\
\text { agriculture }\end{array}$ & Cho et al. (2013) & insignificant & World Bank (2011) \\
\hline Literacy rate & Cho et al. (2013) & insignificant & World Bank (2011) \\
\hline $\begin{array}{l}\text { Mortality rate under } \\
\text { five }\end{array}$ & Cho et al. (2013) & insignificant & World Bank (2011) \\
\hline Infant mortality rate & Bales (2007) & insignificant & World Bank (2011) \\
\hline $\begin{array}{l}\text { Refugees (countries } \\
\text { of asylum) }\end{array}$ & Akee et al. (2010) & positive & World Bank (2011) \\
\hline $\begin{array}{l}\text { Share of migrants in } \\
\text { population }\end{array}$ & Jakobsson and Kotsadam (2013) & insignificant & World Bank (2011) \\
\hline $\begin{array}{l}\text { Share of age group } 65 \\
\text { or above in total } \\
\text { populations }\end{array}$ & Bales (2007) & positive & World Bank (2011) \\
\hline $\begin{array}{l}\text { International tourism } \\
\text { (number of } \\
\text { departure) }\end{array}$ & Cho et al. (2013) & insignificant & World Bank (2011) \\
\hline Urbanization & Cho et al. (2013) & insignificant & World Bank (2011) \\
\hline Visa restriction & Cho et al. (2013) & insignificant & Neumayer (2006) \\
\hline Trade (share in GDP) & $\begin{array}{l}\text { Cho (2013), Danailova-Trainor and Belser } \\
\text { (2006) }\end{array}$ & insignificant/positive & World Bank (2011) \\
\hline
\end{tabular}




\begin{tabular}{|c|c|c|c|}
\hline FDI (share in GDP) & Cho (2013) & insignificant & World Bank (2011) \\
\hline $\begin{array}{l}\text { Share of food, } \\
\text { beverage and tobacco } \\
\text { industries in GDP }\end{array}$ & Bales (2007) & positive & World Bank (2011) \\
\hline Energy use & Bales (2007) & positive & World Bank (2011) \\
\hline Anti-trafficking Policy & Cho et al. (2013) & insignificant & Cho et al. (2014) \\
\hline $\begin{array}{l}\text { Grant amnesty } \\
\text { (protection policy) }\end{array}$ & Akee et al. (2014) & positive & Cho et al. (2014) \\
\hline Crime rate & Jakobsson and Kotsadam (2013) & insignificant & United Nations (2008) \\
\hline $\begin{array}{l}\text { Number of UN } \\
\text { peacekeepers sent } \\
\text { abroad, normalized } \\
\text { by populations }\end{array}$ & Cho et al. (2013) & insignificant & Dreher (2006) \\
\hline $\begin{array}{l}\text { Number of UN } \\
\text { peacekeepers } \\
\text { residing in the } \\
\text { country, normalized } \\
\text { by populations }\end{array}$ & Cho et al. (2013), Smith and Smith (2010) & insignificant/positive & Neumayer and Perkins (2008) \\
\hline $\begin{array}{l}\text { OECD membership } \\
\text { (dummy) }\end{array}$ & Belser (2005), Cho (2013) & positive & OECD (2011) \\
\hline $\begin{array}{l}\text { Regional dummy: East } \\
\text { Asia and Pacific, } \\
\text { Europe and Central } \\
\text { Asia, Latin America } \\
\text { and Caribbean, North } \\
\text { Africa and Middle } \\
\text { East, North America, } \\
\text { South Asia, and Sub- } \\
\text { Saharan Africa (7 } \\
\text { variables) }\end{array}$ & Belser (2005), Cho et al. (2013) & $\begin{array}{l}\text { negative/insignificant } \\
\text { (reference group: } \\
\text { developed country- } \\
\text { group) }\end{array}$ & World Bank (2011) \\
\hline $\begin{array}{l}\text { Share of Religion in } \\
\text { populations: Muslim, } \\
\text { Catholic, and } \\
\text { Protestants ( } 3 \\
\text { variables) }\end{array}$ & Cho et al. (2013) & $\begin{array}{l}\text { partly negative } \\
\text { (Catholic) }\end{array}$ & Encyclopedia Britannica (2001) \\
\hline $\begin{array}{l}\text { Legal origin: British, } \\
\text { socialist, French, and } \\
\text { German dummy (4 } \\
\text { variables) }\end{array}$ & Akee et al. (2014), Cho et al. (2013) & mostly insignificant & La Porta et al. (1998) \\
\hline $\begin{array}{l}\text { Major language: } \\
\text { English, French, } \\
\text { Spanish, Portuguese, } \\
\text { and German dummy } \\
\text { (5 variables) }\end{array}$ & Cho et al. (2013) & insignificant & Encyclopedia Britannica (2001) \\
\hline $\begin{array}{l}\text { Transition economy } \\
\text { (dummy) }\end{array}$ & Akee et al. (2014) & negative & OECD (2011) \\
\hline $\begin{array}{l}\text { Landlocked country } \\
\text { (dummy) }\end{array}$ & Akee et al. $(2010,2012,2014)$ & negative & Mayer and Zignago (2011) \\
\hline
\end{tabular}


Appendix D. Human trafficking flows.

1. Inflows: Destination country list (source: UNODC, 2006).

\begin{tabular}{|c|c|c|c|c|}
\hline Very High & High & Medium & Low & Very Low \\
\hline Belgium & Australia & Albania & Aruba & Algeria \\
\hline Germany & Austria & Argentina & Bangladesh & Bhutan \\
\hline Greece & Bosnia and & Bahrain & Belize & Brazil \\
\hline Israel & Herzegovina & Benin & Brunei Darussalam & Burundi \\
\hline Italy & Cambodia & Bulgaria & Congo, Republic of & Chad \\
\hline Japan & Canada & Burkina Faso & Costa Rica & Chile \\
\hline Netherlands & China & Cameroon & Ecuador & Congo, Democratic \\
\hline Thailand & Hong Kong, China & Cote d'Ivoire & Egypt & Republic of \\
\hline Turkey & SAR & Croatia & Haiti & Djibouti \\
\hline \multirow{44}{*}{ America } & Taiwan Province of & Curacao & Indonesia & Dominica \\
\hline & China & Dominican Republic & Iraq & Ethiopia \\
\hline & Cyprus & El Salvador & Ireland & Fiji \\
\hline & Czech Republic & Equatorial Guinea & Kyrgyzstan & Gambia \\
\hline & Denmark & Estonia & Lao People's & Georgia \\
\hline & France & Finland & Democratic & Honduras \\
\hline & India & Gabon & Republic & Jamaica \\
\hline & Kosovo, & Ghana & Libyan Arab & Liberia \\
\hline & (Serbia and & Guatemala & Jamahiriya & Malawi \\
\hline & Montenegro) & Hungary & Luxembourg & Maldives \\
\hline & Pakistan & Iceland & Mali & Morocco \\
\hline & Poland & Iran & Niger & Mozambique \\
\hline & Saudi Arabia & Kazakhstan & Oman & Republic of \\
\hline & Spain & Kenya & Paraguay & Moldova \\
\hline & Switzerland & Kuwait & Romania & Senegal \\
\hline & United Arab & Latvia & Slovenia & Sierra Leone \\
\hline & Emirates & Lebanon & Sri Lanka & Slovakia \\
\hline & United Kingdom & Lithuania & Uganda & Sudan \\
\hline & & Macao, China SAR & United Republic of & Tajikistan \\
\hline & & Malaysia & Tanzania & Trinidad and \\
\hline & & Mexico & Uzbekistan & Tobago \\
\hline & & Myanmar & Yemen & Zambia \\
\hline & & New Zealand & & Zimbabwe \\
\hline & & Nigeria & & \\
\hline & & Norway & & \\
\hline & & Panama & & \\
\hline & & Philippines & & \\
\hline & & Portugal & & \\
\hline & & Qatar & & \\
\hline & & Republic of Korea & & \\
\hline & & Russian Federation & & \\
\hline & & Serbia and & & \\
\hline & & Montenegro & & \\
\hline & & Singapore & & \\
\hline & & South Africa & & \\
\hline & & Sweden & & \\
\hline & & Syrian Arab & & \\
\hline & & Republic & & \\
\hline & & The former Yugoslav & & \\
\hline & & Macedonia & & \\
\hline & & Togo & & \\
\hline & & Ukraine & & \\
\hline & & Venezuela & & \\
\hline & & Vietnam & & \\
\hline
\end{tabular}


2. Outflows: Origin country list (source: UNODC, 2006).

\begin{tabular}{|c|c|c|c|c|}
\hline Very High & High & Medium & Low & Very Low \\
\hline Albania & Armenia & Afghanistan & Argentina & Brunei \\
\hline Belarus & Bangladesh & Algeria & Bhutan & Chad \\
\hline Bulgaria & Benin & Angola & Botswana & Chile \\
\hline China & Brazil & Azerbaijan & Burundi & Costa Rica \\
\hline Lithuania & Cambodia & Bosnia & Canada & Egypt \\
\hline Nigeria & Colombia & Burkina Faso & Cape Verde & Fiji \\
\hline Moldova & Czech Republic & Cameroon & Congo, DR & Jamaica \\
\hline Romania & Dominican & Congo & Djibouti & Macao \\
\hline Russia & Estonia & Cote d’Ivoire & Eq. Guinea & Netherlands \\
\hline Thailand & Georgia & Croatia & Eritrea & Paraguay \\
\hline \multirow[t]{36}{*}{ Ukraine } & Ghana & Cuba & Gabon & Syria \\
\hline & Guatemala & North Korea & Gambia & Uruguay \\
\hline & Hungary & Ecuador & Guinea & Yemen \\
\hline & India & El Salvador & Iran & \\
\hline & Kazakhstan & Ethiopia & Iraq & \\
\hline & Lao & Haiti & Jordan & \\
\hline & Latvia & Honduras & Lebanon & \\
\hline & Mexico & Hong Kong & Lesotho & \\
\hline & Morocco & Indonesia & Madagascar & \\
\hline & Myanmar & Kenya & Maldives & \\
\hline & Nepal & Kosovo & Nicaragua & \\
\hline & Pakistan & Kyrgyzstan & Panama & \\
\hline & Philippines & Liberia & Rwanda & \\
\hline & Poland & Malawi & South Korea & \\
\hline & Slovakia & Malaysia & Somalia & \\
\hline & Uzbekistan & Mali & Sudan & \\
\hline & Vietnam & Mozambique & Swaziland & \\
\hline & & Niger & Tunisia & \\
\hline & & Peru & USA & \\
\hline & & Senegal & Zimbabwe & \\
\hline & & Serbia and Montenegro & & \\
\hline & & Sierra Leone & & \\
\hline & & Singapore & & \\
\hline & & Slovenia & & \\
\hline & & South Africa & & \\
\hline & & Sri Lanka & & \\
\hline & & Macedonia & & \\
\hline & & Taiwan & & \\
\hline & & Tajikistan & & \\
\hline & & Togo & & \\
\hline & & Turkey & & \\
\hline & & Turkmenistan & & \\
\hline & & Uganda & & \\
\hline & & Tanzania & & \\
\hline & & Venezuela & & \\
\hline & & Zambia & & \\
\hline
\end{tabular}

Note: Countries with no (reported) in-/outflows are not listed here. 